\title{
TH1/TH2 PATTERN OF RENAL TISSUES IN ACUTE AND CHRONIC ANIMAL MODELS TREATED WITH MESENCHYMAL STEM CELLS
}

\author{
Padrão TH1/TH2 em tecidos renais de modelos agudo e crônico tratados \\ com células-tronco mesenquimais
}

\begin{abstract}
Patricia Semedo', Carolina Gardini Palasio', Cassiano Donizetti Oliveira1 , Carla Quarim Feitoza', Giselle Martins Gonçalves', Pamella Mei Wang ${ }^{1}$, Marcos Antonio Cenedeze', Vicente de PaulaTeixeira², Marlene Antônia dos Reis², Alvaro Pacheco-Silva1, Niels Olsen Saraiva Câmara ${ }^{1,3}$
\end{abstract}

\begin{abstract}
Mesenchymal stem cell (MSC) therapy is a promising new therapy for kidney diseases. Many authors have been demonstrated that the MSC treatment leads to $\mathrm{N}$ improvement of the renal function in acute damaged models. However, the way it works still remains elusive. Purpose: To evaluate whether the renal protection provided by MSC administration seen in acute and chronic renal remnant damaged models involves modulation of the inflammation. Methods: MSC were attained from bone marrow of male Wistar rats. Female Wistar were subjected to ischemia-reperfusion damage by clamping renal pedicles for 1 hour. After a $6 \mathrm{~h}$ reperfusion, $2.10^{5} \mathrm{MSC}$ were administrated i.v. in the chronic model. The nephrectomy models 5/6 were treated with $1.10^{6} \mathrm{MSC}$ administered i.v. after two weeks. Results: After a $24 \mathrm{~h}$ reperfusion, MSC-treated animals presented a significant improvement of the renal function associated to decreased levels of IL-1 $\beta$, IL-6 and TNF- $\alpha$ gene expression. Interestingly, the IL-4 mRNA expression increased in parallel. Furthermore, a higher expression of PCNA and an increase in the Bcl2/Bad ratio were seen in kidney tissues of MSC-treated animals. In the remnant model, this modulation in the cytokine pattern was sustained, despite a lack of amelioration of the renal dysfunction. Moreover, the expressions of TGF- $\beta$, MMP-9, TIMP-1 and Smad7 were not altered, although PAI-1 was significantly decreased. Conclusion: MSC therapy can indeed modulate the inflammatory response following acute and chronic renal injuries, accelerating the tubular repair; however, long-term outcomes seem not to be halted by this therapy.
\end{abstract}

Keywords: Mesenchymal Stem Cell Transplantation; Renal Insufficiency, Acute; Renal Insufficiency, Chronic.

Instituição:

1 Laboratório de Imunologia Clínica e Experimental. Division of Nephrology. Universidade Federal de São Paulo, Escola Paulista de Medicina, São Paulo, Brazil.

${ }^{2}$ General Pathology Division, Triangulo Mineiro Medical School, Uberaba, Minas Gerais, Brazil.

${ }^{3}$ Laboratory of Transplantation Immunology. Department of Immunology, Universidade de São Paulo, São Paulo, Brazil.

Mail Address?

Niels Olsen Saraiva Câmara, M.D.

Department of Immunology - Institute of Biomedical Science IV - Universidade de São Paulo,

Rua Prof Lineu Prestes, 1730

CEP 05508-900 - São Paulo - SP - Brazil

Tel.: 5511 3091-7388 / Fax: 5511 3091-7224

E-mail: niels@icb.usp.br

Support: This work was supported by the Brazilian Foundation - FAPESP (Fundação de Apoio à Pesquisa do Estado de São Paulo), Grants Numbers: 2006/00620-5, 04/13826-5, 04/08226-9), CNPq (04113826-5) and Ministério da Saúde.

Recebido em: 10.03 .2007

Aceito em: 05.06.2007

\section{INTRODUCTION}

Despite all development in patient's care and new therapies to treat acute renal failure (ARF), this condition is still associated to a high mortality. ARF is mainly due to ischemic or toxic renal injuries. Pathogenesis of such disorder goes further than the interplay between vascular and tubular factors. Also, there is an important role of the endothelium and the immune response, since ARF is considered an inflammatory event. ${ }^{1-3}$ During ischemia and reperfusion injury (IRI), renal endothelium and parenchymal cells secrete pro-inflammatory cytokines (TNF- $\alpha$, IL-1, IL-6), chemokines and also activating the complementary pathway leading to an amplification of the inflammatory processes. ${ }^{4,5}$ These endproducts associated to the generated reactive oxygen species (ROS) up-regulate the expression of adhesion molecules, such as ICAM, VCAM and P-selectin, promoting the recruitment of leukocytes into the tissue. ${ }^{6}$ These cells can further secrete cytokines and sustain this inflammatory loop.

Injured tubular cells that do not die or detach from the basement membrane are thought to contribute to the tubular epithelium regeneration and to the overall renal function restoration. 
Up-regulation of genes, protein synthesis, and the entry into the cell cycle are necessary to the cell repairing, migration, and proliferation involved in the renal regeneration process. ${ }^{7-10}$

Regeneration process is not a synonymous of tubular repair. The parenchyma has also an important role in this process. Initially, after an injury, myofibroblasts produce matrix metalloproteinases (MMP) that disrupt the basement membrane, allowing the efficient recruitment of inflammatory cells into the site of injury. By the action of pro-fibrotic cytokines such as TGF- $\beta$, myofibroblasts produce extracellular matrix components and they migrate to the injured site. The origin of those cells is still controversy; they can be derived from local mesenchymal cells recruited from the bone marrow (also named fibrocytes), or derived by epithelialmesenchymal transition (EMT). ${ }^{11}$

The mesenchymal stem cell (MSC), other population of the bone marrow stem cell resident, seems to play a role by protecting these events along the renal IRI. First described by Friedenstein ${ }^{12}$, the International Society for Cellular Therapy has defined MSC by three criteria ${ }^{13}$ :

1. MSC must be plastic-adherent when maintained in standard culture conditions.

2. MSC must express CD105, CD73 and CD90, and lack expression of CD45, CD34, CD14 or CD11b, CD79alpha or CD19 and HLADR surface molecules.

3. MSC must differentiate from in vitro osteoblasts, adipocytes and chondroblasts.

Many studies have shown that the MSC therapy leads to an early recovery from acute kidney injury. ${ }^{14-21}$ However, there is not a consensus on how these MSC work on this disorder. Some studies indicate that MSC can differentiate into small numbers of tubular epithelial cells, peritubular vascular endothelial cells, or both. Female mouse kidney recipients of male bone marrow grafts showed co-localization of Y-chromosomes and tubular epithelial markers. ${ }^{20}$ In addition, injection of MSC of male bone marrow origin remarkably protected cisplatin-treated syngeneic female mice from renal function impairment and severe tubular injury. During such repair, MSC engrafted the damaged kidney and differentiated into tubular epithelial cells. ${ }^{17}$

However, the demonstration that MSC can actually take the place of the injured tubular cells has not been confirmed by different investigators using different experimental models. ${ }^{15,16,19,21,23}$ One interesting possibility is that the BMSC secrete factors that can augment the capacity of resident renal stem cells to proliferate and entering the tubule during the repair process, or can prevent the tubular cell death and/or enhance proliferation by an endocrine effect on the tubular cell itself, or, finally, it can promote the suppression of the inflammatory responses. In such sense, MSC are able to suppress the activity of a broad range of immune cells, including $\mathrm{T}$ cells, antigen-presenting cells, natural killer (NK) cells and B cells. Added to this, MSC secrete several growth factors, mainly the TGF- $\beta$ and Wnt proteins, which are important for their development and maintenance, and for nephrogenesis. ${ }^{24}$ ${ }^{27}$ MSC may use different mechanism to repair a tissue, and this could be crucial when considering the complex pathophysiology of almost all diseases. ${ }^{28}$

The long-term consequences of an ischemia can irreversibly damage kidneys. Cellular infiltration, extracellular matrix changes, cell turnover and immune response are worsened after a long regeneration period in ischemic kidneys. ${ }^{29}$ Indeed, one single episode of severe warm ischemic injury to the kidney is associated to significant long-term kidney inflammation, and particularly CD4+ T cells infiltration. ${ }^{30}$ Thus, IRI should be considered a continuous inflammatory condition that can ultimately promote tissue fibrosis.

So far, these works of MSC on renal IRI had focused on acute events, with few of them showing long-term outcomes after the initial acute injury. Herein, we aimed to exploit the modulator role of MSC in early stages of an acute phase of renal injury combined with the role in the long-term phase of a chronic model.

\section{MATERIALS AND METHODS}

\section{Isolation and characterization of mesenchymal stem cells}

Whole bone marrow was collected from limb bones of male Wistar-EPM rats, with weights ranging from $180 \mathrm{~g}$ to $250 \mathrm{~g}$. Animals were sacrificed with lethally anesthetic doses in accordance to a protocol approved by the Universidade Federal de São Paulo UNIFESP (CEP: 0210-2006 and 0179-2007). A density gradient was used to isolate blood mononuclear fraction of whole bone marrow. These isolated cells were cultured at DMEM-low glucose (Invitrogen, Carlsbad, USA), 10\% FBS (Cultilab, Campinas, Brazil) and antibiotics (Invitrogen, Carlsbad, USA). Flow cytometry analysis (FACS Canto, Becton Dickinson, San Jose, USA) were done for CD73, CD45, CD31, CD29, CD44 and CD90 molecules (all purchased from BD Biosciences Pharmingen, USA). The differentiation potential was examined by culturing these cells under favorable conditions for adipogenic and osteogenic differentiation, as previously described. ${ }^{31}$

\section{Ischemia-Reperfusion model}

IRI was induced in anesthetized (ketamine/xylazine) adult females Wistar-EPM rats, with weights ranging from 250 to $300 \mathrm{~g}$, by bilateral clamping of the renal pedicles with nontraumatic microaneurysm clamps for 60 minutes (Rocca, São Paulo, Brazil). After the clamps were removed, reperfusion of the kidneys was visually confirmed. 6 hours after the injury, MSC were administered by i.v. injections of $2 \times 10^{5}$ cells per animal. There were 3 groups in each time point: (1) IRI 24 and 48h: animals were subjected to injury and sacrificed after a 24 and 48 hours reperfusion, (2) IRI 24 and $48 \mathrm{~h}$ MSC animals were subjected to injury, and after 6 hours, the MSC was i.v. administered. (3) IRI sham: each animal was subjected to surgery without clamping the pedicles. Blood was collected to determine the plasma creatinine and urea before surgery and after reperfusion. Kidneys were colleted for immunohistochemistry and qRT-PCR.

\section{Remnant kidney model}

Under anesthesia, adult female Wistar-EPM rats (200-250g) underwent $5 / 6$ nephrectomy $(5 / 6 \mathrm{Nx})$ by selective infarction of approximately two-thirds of the left kidney by ligation of two or three branches of the renal artery. After two weeks, the right kidney was the removed. Every two weeks animals were submitted to metabolic cage and $24 \mathrm{~h}$ urine was colleted for the proteinuria measurement. Two weeks after the last surgery, about $1 \times 10^{6} \mathrm{MSC}$ were intravenously administered per animal. After 8 and 12 
weeks after administering MSC, animals were sacrificed. Blood was collected from rats to determine the before surgery plasma creatinine and urea, as well as on weeks two and eight after the first surgery and at the day of the sacrifice (12 wks). Kidneys were colleted to immunohistochemistry and qRT-PCR.

\section{Functional analyses}

Serum and urine creatinine were determined by a colorimetric method based on the Jaffe' reaction. A Labstest Kit measured the serum urea and protein level of the urine, according to the manufacturer's recommendations. (Labtest, Lagoa Santa, MG, Brazil).

\section{qRT-PCR}

Total RNA was isolated from whole kidneys with TRlzol Reagent (Life Technologies, Carlsbald, USA). Contaminated genomic DNA was removed using RNase-free deoxyribonuclease, DNase I (Amersham, Upsala, Sweden). Reverse transcriptase reaction was performed using M-MLV (Promega, Madison, USA). qRTPCR was carried out using ABI PRISM 7300 Sequence Detector (Applied Biosystems, Foster City, USA), using TaqMan (Applied Biosystems, Foster City, USA) for HPRT, IL-1 $\beta$, IL-4, IL-6, IL-10 and TNF following the manufacturer's recommendations. Also, some primers for rat were synthesized for MCP-1, TGF $\beta$, PAI-1 and Smad7 amplification. Primers were designed to amplify an $80-120-\mathrm{bp}$ fragment with $50^{\circ}-65^{\circ} \mathrm{C}$ annealing temperature. The total volume of each reaction was $10 \mu \mathrm{l}$, containing 10 $\mu \mathrm{M}$ forward and $10 \mu \mathrm{M}$ reverse primer, and $2 \mu \mathrm{g}$ of cDNA. Appropriate negative controls were run for each reaction. All reactions were triplicate. Sequences of rat primers were as follows: MCP-1: forward 5'AAGAGAATCACCAGCAGCAGGT3' and reverse 5' TTCTGGACCCATTCCTTATTGG 3', TGF $\beta$ : forward 5' TCAGTCCCAAACGTCGAGGT 3' and reverse 5' TCAGTCCCAAACGTCGAGGT 3', PAI-1: forward 5'GACTGACATCTTCAGCTCAACCC3' and reverse 5' TCACCTCGATCTTGACCTTTTGT3', and Smad7: forward 5' GTGCAACCCCATCACCTTA 3' and reverse 5' GGACAGTCTGCAGTTGGTTTGA 3'.

\section{PCNA Immunohistochemistry}

Kidneys were formalin-fixed and embedded in paraffin. Sections were de-paraffinized, submitted to antigen retrieval $(10 \mathrm{mmol} / \mathrm{L}$ citrate buffer, $\mathrm{pH}$ 6.0) and quenched for endogenous peroxidase (with $3 \% \mathrm{H}_{2} \mathrm{O}_{2}$ ). Antibody against PCNA (Dako EPOS) was used, following the manufacturer's instruction as to the staining procedure.

\section{Statistical analysis}

Data are expressed as mean $\pm \mathrm{SD}$, and were analyzed by ANOVA for multiple comparison or Student t test using Prism software (Graph Pad, San Diego, USA). $P$ values $<0.05$ were considered significant.

\section{RESULTS}

\section{MSC isolation, differentiation and immune phenotype}

MSC from tibia and femur of male Wistar-EPM rats were isolated by gradient density and then maintained in culture for just 5 passages. They are fibroblast-like in appearance (data not shown). Cell surface immune phenotype showed they were positive for CD44, CD73,
CD29 and CD90 and negative for CD31 and CD45 (Figure 1), similar to the results attained by other authors. ${ }^{31,32}$ Also, to further characterize as MSC, they were cultured on specific medium that allowed adipogenic or osteogenic differentiation.

Figure 1: Rat mesenchymal stem cell (RMSC) submitted to citometry analyses. RMSC were treated with trypsine and incubated with cell surface markers labeled with FITC or PE. After 30minutes, cells were analyzed using a FACS-Calibur (BD. A RMSC positive labeled for CD44-B RMSC positive labeled for CD73. C RMSC positive labeled for CD29 D RMSC negative labeled for CD45 E RMSC negative labeled for CD31 and F: RMSC positive labeled for CD90.

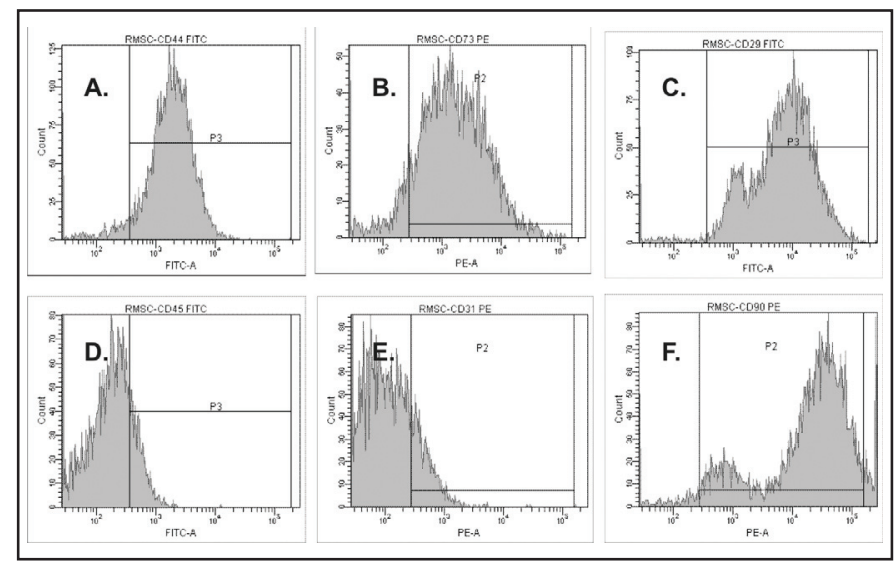

\section{SHORT-TERM OUTCOMES OF THERAPY WITH MSC}

Administration of MSC was performed after 6h reperfusion, since MSC must migrate to the injury site driven by an unknown stimulus. $6 \mathrm{~h}$ hour after reperfusion, the serum creatinine and serum urea levels were higher compared to basal levels (Figure $2 \mathrm{C}$ and D), but they were similar between groups treated with saline and with MSC. As previous works have already shown, renal function of animals subjected to IRI and treated with MSC presented the lowest serum creatinine and urea levels compared to non-treated animals (Figure 2). More importantly, the effects of MSC administration were sustained even 48 hours after reperfusion (Figure 2D).

Figure 2: Serum creatinine and urea level after 24 and $48 \mathrm{~h}$ of reperfusion A. Serum creatinine after $24 \mathrm{~h}$ of reperfusion and. (B) Serum urea level. C. Serum creatinine after $48 \mathrm{~h}$ of reperfusion and serum urea level (D). Data expressed as mean $\pm S D$ and $P$, statistical difference.

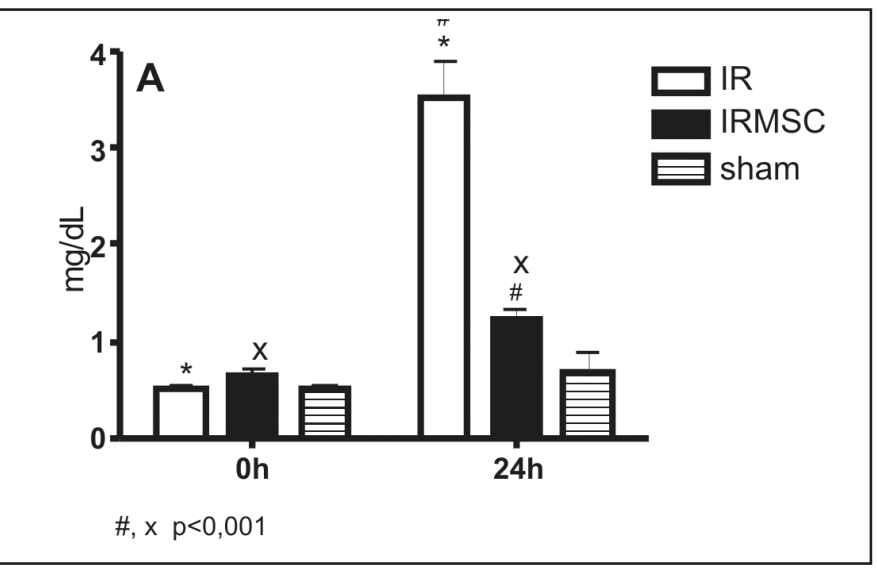


712 Patricia Semedol, Carolina Gardini Palasio ${ }^{l}$, Cassiano Donizetti Oliveiral, Carla Quarim Feitozal', Giselle Martins Gonçalves ${ }^{l}$, Pamella Mei Wang ${ }^{l}$, Marcos Antonio Cenedeze ${ }^{l}$, Vicente de Paula Teixeira' ${ }^{2}$; Marlene Antônia dos Reis' ${ }^{2}$, Alvaro Pacheco-Silval, Niels Olsen Saraiva Câmara ${ }^{1,3}$.
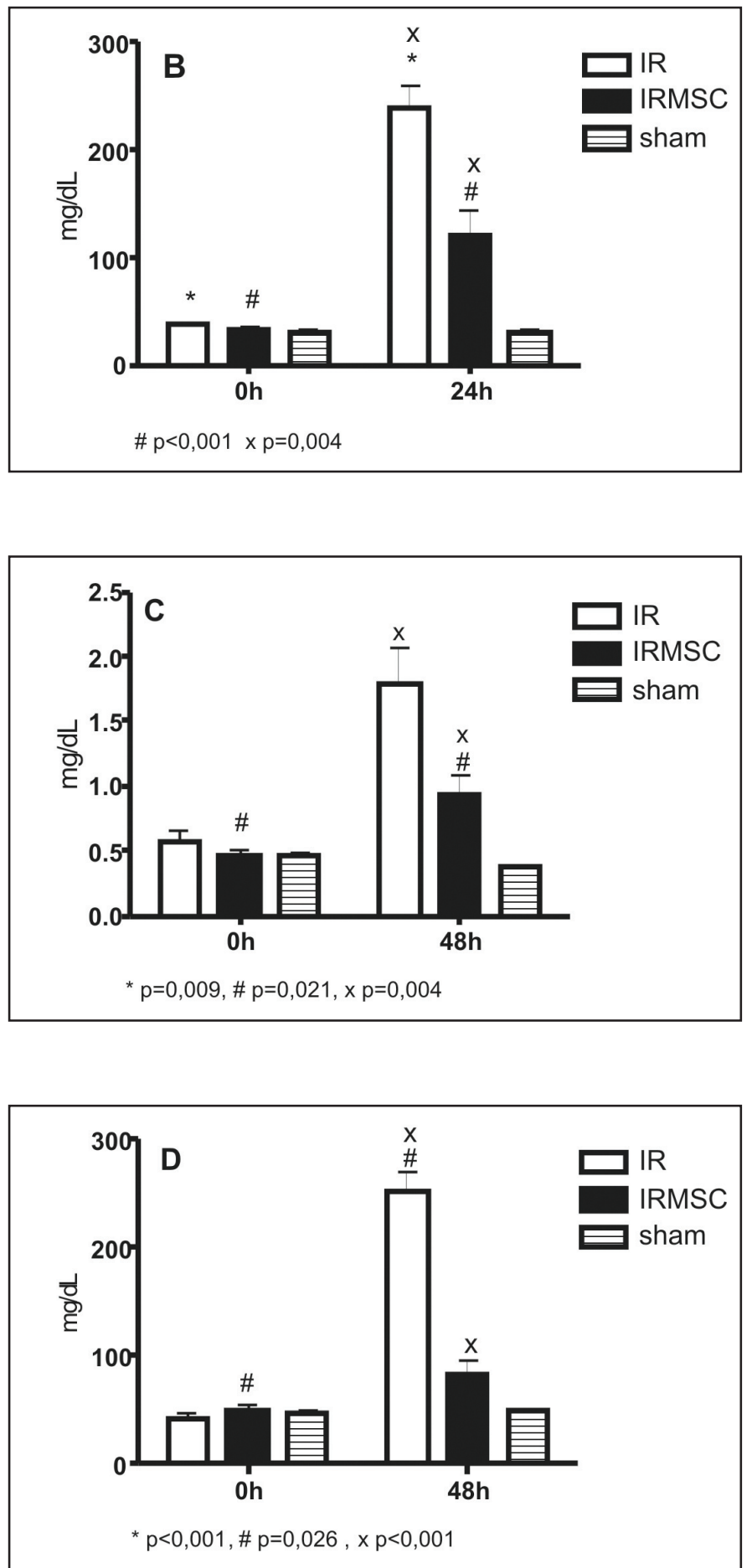

Next, the expression of some cytokines in the whole kidney was assessed. It is well established that IRI is an inflammatory syndrome where Th1-related cytokines play a detrimental role, while Th2prone cytokines have a relative protective function. Analyzing all cytokines at 24 hours, we saw that IL-4 and IL-10 two antiinflammatory cytokines, were highly expressed in MSC-treated animals compared to control animals. At 48 hours, such panel has changed, and the levels of both molecules were down regulated.
Instead, IL-6 and TNF- $\alpha$ mRNA were over expressed in MSC treated animals and those not treated at all (Figure 3A and $\mathrm{B}$ ). However, the TNF- $\alpha$ expression in MSC-treated animals was lower compared to non-treated ones, with no statistical significance.

Figure 3: Gene expression in IR kidney of MSC treated and non-treated animals, generated by referencing each gene to HPRT as an internal control. MSC administration 24h (IRMSC) after reperfusion significantly reduces $I L-1 b, I L-6$ and TNF at kidney compared to non-treated animals. On the other hand, there is an increasing expression of IL-4 and TNF, but they are not significantly statistic, comparing to non-treated animals (A). Cytokines expression at kidney after $48 \mathrm{~h}$ of reperfusion at sham, non-treated animals (IR) and 6 h after reperfusion MSC-treated animal (IRMSC) (B). Data expressed as mean of $\Delta \Delta C t$ normalized with a control animal $\pm S D$ and $P$. statistical difference.
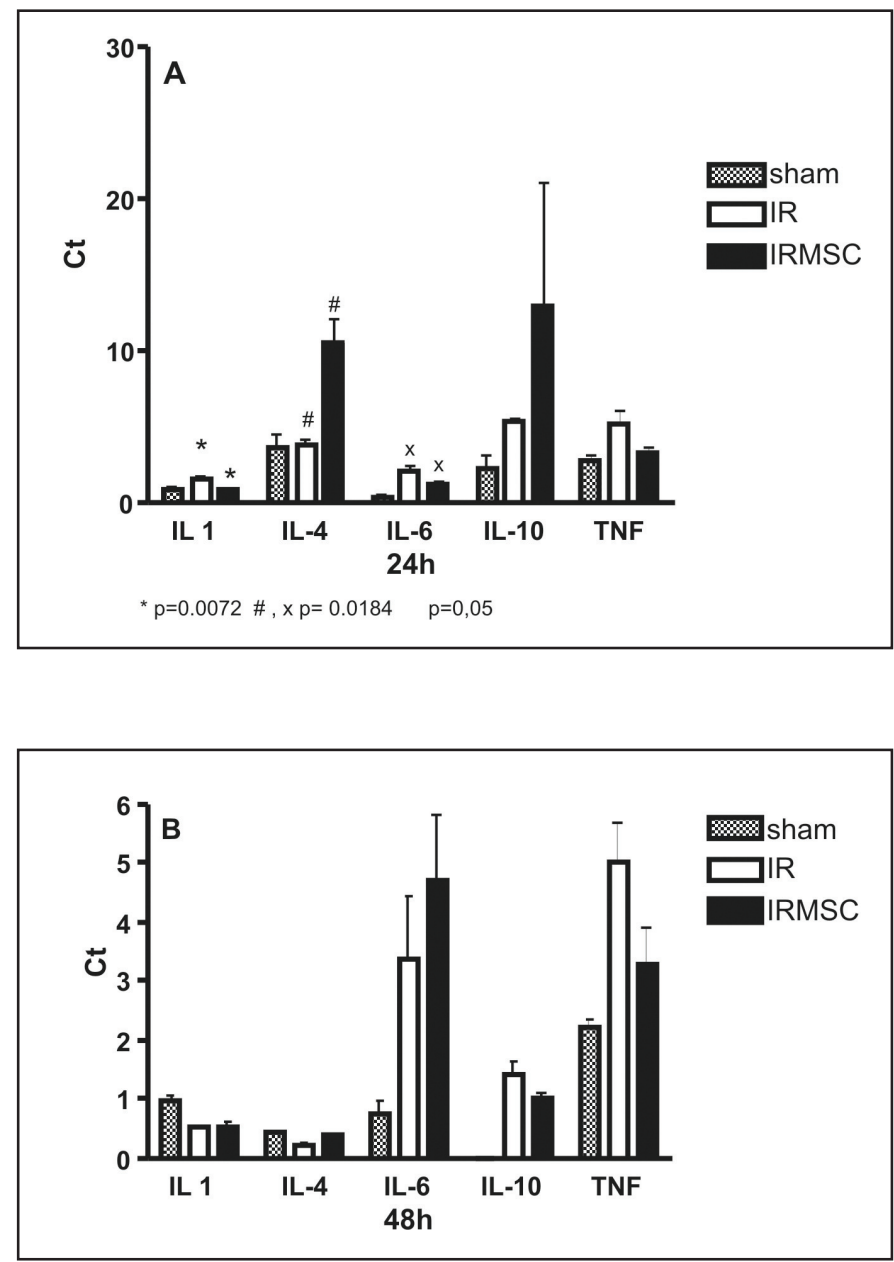

Despite the treatment, tubular cells regenerate after an ischemic injury. Such tubular regeneration can be demonstrated by the quantification of the proliferating cell nuclear antigen (PCNA) by immunohistochemistry. Our data demonstrated that MSC-treated animals presented an enhanced PCNA-positive cells compared to controls mainly 24 hours after reperfusion (IRI MSC-treated: $0.33 \%$ of stained nuclei per total area vs. IRI saline-treated: $0.12 \%$ of stained nuclei) (Figure 4A). Furthermore, we choose to quantify the apoptosis rate in ischemic kidneys in animals treated or not with MSC. This additional study will complement data attained with PCNA. Next, we amplified the mRNA of an anti-apoptotic, 
Bcl-2, and a pro-apoptotic bad molecule, and hope to demonstrate a susceptibility or a resistance to programmed cell death in our study. After a 24 hours reperfusion, MSC-treated animals had higher ratio of $\mathrm{Bcl} 2 / \mathrm{Bad}$ compared to non-treated ones, demonstrating the antiapoptotic action of this therapy (Figure 4B)

Figure 4: PCNA immunohistochemistry of kidney after 24h of reperfusion. (A) Percentage of stained nuclei at total area of tissue. We observed more nuclei stained at MSC treated animal than in non-treated animal. (B) Comparison of $\mathrm{Bcl} 2$ and Bad ratio. Bcl2/Bad is more preeminent at $24 \mathrm{~h}$ MSC-treated than in non-treated animals. Data expressed as mean $\pm S D$.
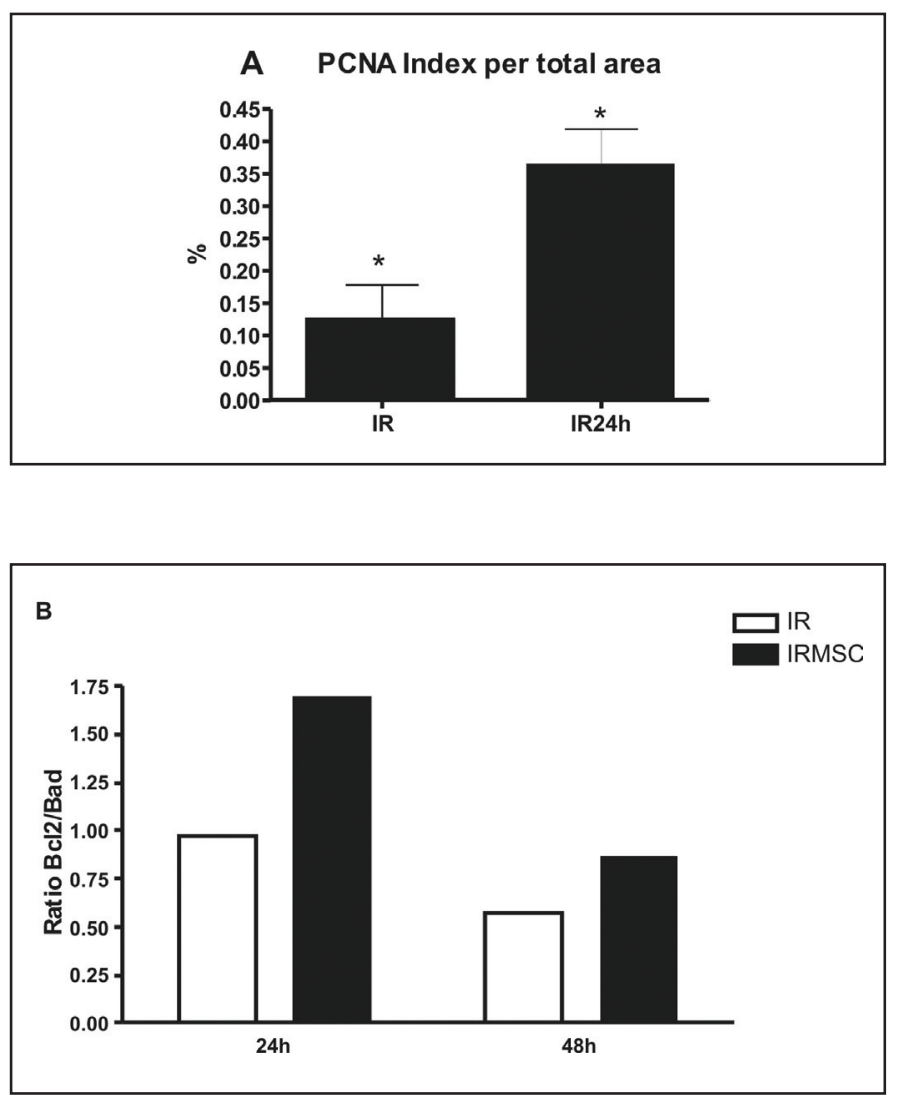

Long-term outcomes of a therapy with MSC

Renal fibrosis is a final pathway of end-stage renal diseases (ESRD), affecting the interstitial vessels and glomeruli. Unfortunately, no single animal model can reproduce all features seen in humans. We studied a remnant model that provides glomerulosclerosis and interstitial fibrosis in a comparable extension. ${ }^{32}$

Therefore, we studied the effects of MSC in the remnant model animal. We observed higher serum creatinine levels in nontreated animals and in MSC-treated animals after 12 weeks of MSC administration, compared to sham-operated animals (Figure $5 \mathrm{~A}$ ). Total protein excretion at $24 \mathrm{~h}$-urine normalized to urinary creatinine showed that more proteins were excreted in non-treated animals than in MSC-treated animal (Figure 5B).

Once again, we quantified pro-inflammatory cytokines hoping to visualize mechanisms behind the effect of the MSC therapy. The cytokines profile in the remnant model showed that IL-4 expression levels increased, while IL- $1 \beta$ levels decreased in the
MSC-treated animals compared to non-treated animals (Figure 6A). MCP-1, TGF $\beta$, Smad7 and PAI-1 mRNA tended to decrease in the MSC-treated animal (Figure 6B). Only PAI-1 RNAm expression decreases at MSC-treated animal in a significant way. The expression of metalloproteinase 9 and its inhibitor (TIMP-1) were presented at a reduced level in the MSC-treated animals.

Figure 5: A: Serum creatinine level of 5/6 nephrectomized rats at day 0 , after 2 weeks and 12 weeks. Nx is the animal subjected to 5/6 nephrectomy surgery. Nx MSC is the animal subjected to surgery with MSC intravenously administrated after two weeks of established model. Data expressed as mean $\pm S D$ and $P$, statistical difference. Protein level at $24 \mathrm{~h}$ urine at $B$, analyzed each 2 week. Protein levels are presented normalized with urinary creatinine. We can observe that the remnant model leads to increase of proteinuria, and MSC treatment decreases this ratio at 12 weeks. Data expressed as ratio of urinary $24 \mathrm{~h}$ protein/ urinary creatinine.
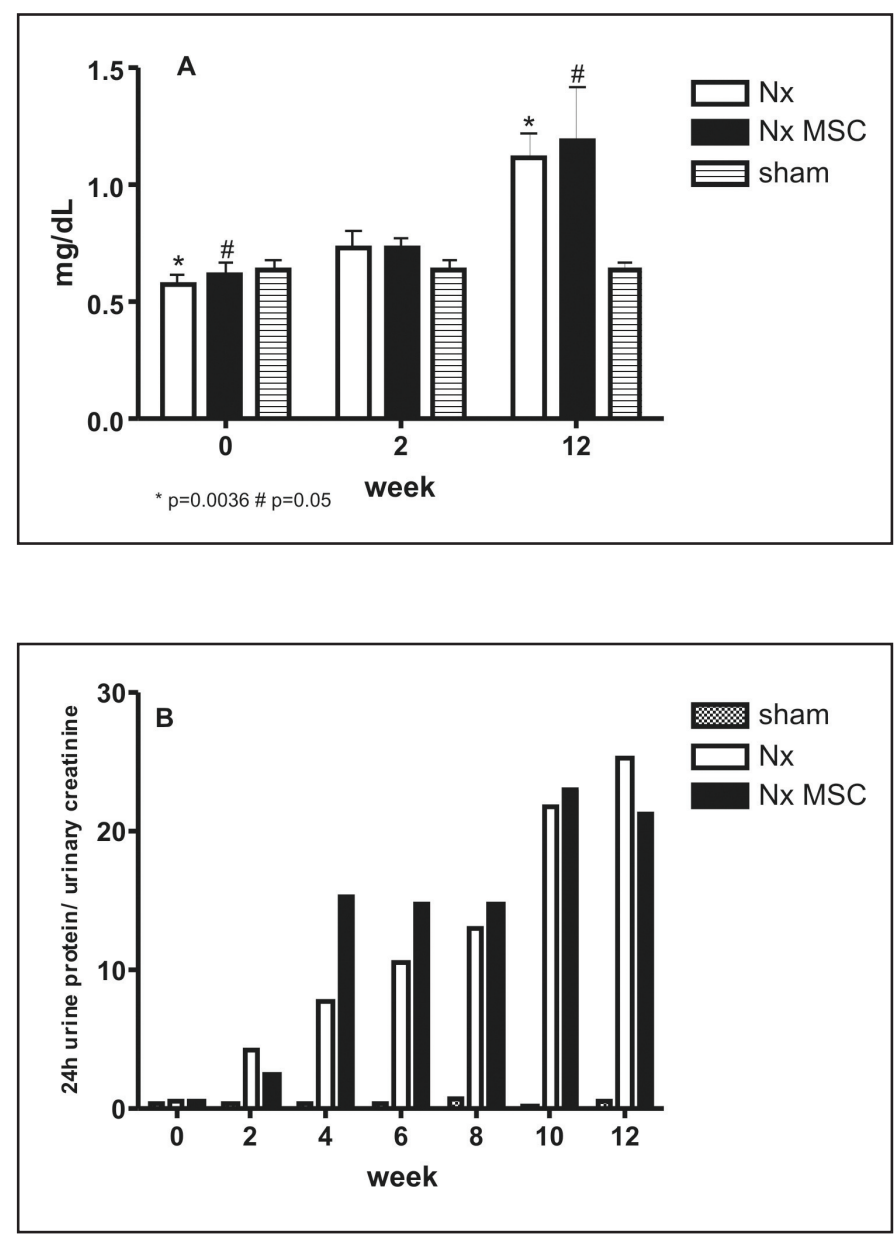

Figure 6: $A: I L-1 \beta$ and IL-4 expression at 5/6 nephrectomized kidney. There is a higher IL-4 expression and lower IL-1 $\beta$ expression at MSC-treated animals (Nx MSC) comparing to non-treated animals (Nx). Cytokine profile was generated by referencing each gene to HPRT as an internal control. Data expressed as mean of $\Delta \Delta C t$ normalized with a control animal $\pm S D$ and P, statistical difference. B: Expression profile of MCP-1, TGF $\beta$, Smad7 and PAI-1 at whole kidney of remnant model animals. There is a tendency to decrease MCP-1, TGF and Smad7 but the only one with statistically difference between MSC-treated and non-treated was PAI-1 expression. Cytokine profile was generated by referencing each gene to HPRT as an internal control. Data expressed as mean of $\Delta \Delta C t$ normalized with a control animal $\pm S D$ and $P$. statistical difference. $C$ : Matrix remodeling molecules expression MMP-9 and its inhibitor, TIMP-1. No significant differences were 
714 Patricia Semedol, Carolina Gardini Palasio ${ }^{l}$, Cassiano Donizetti Oliveiral, Carla Quarim Feitozal , Giselle Martins Gonçalves ${ }^{l}$, Pamella Mei Wang ${ }^{l}$, Marcos Antonio Cenedeze ${ }^{l}$, Vicente de Paula Teixeira ${ }^{2}$; Marlene Antônia dos Reis ${ }^{2}$, Alvaro Pacheco-Silval, Niels Olsen Saraiva Câmara ${ }^{l, 3}$.

observed. It seems that MMP-9 and TIMP-1 are less expressed at kidney from MSC treated animal (Nx MSC). Cytokine profile was generated by referencing each gene to HPRT as an internal control. Data expressed as mean of $\Delta \Delta C t \pm S D$, normalized with a control animal.
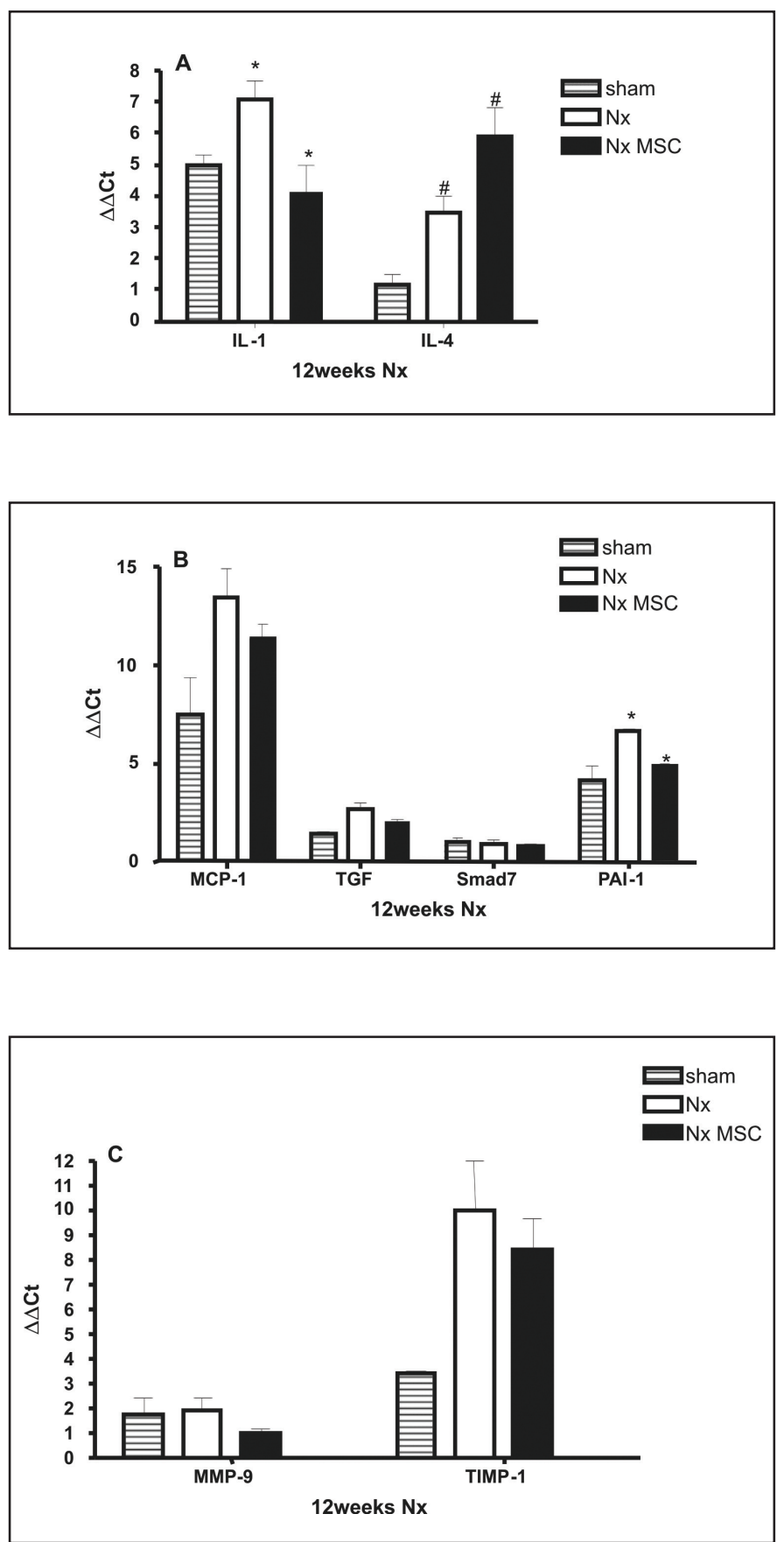

\section{DISCUSSION}

Acute renal failure is a common disease that unfortunately is still related to high mortality $(\sim 50 \%)$. Critical care patients and transplanted recipients are the most affected with this disorder. Once an ischemic event occurs, it seems that whenever inflammatory stimuli persist, they may lead to fibrosis.
Initially, we performed some studies to demonstrate that our population of adherent cells was indeed MSC. The immune phenotype of some surface cell markers and the differentiation for adipocyte and osteocyte are the gold-standard experiments to characterize MSC. MSC must be negative for CD45 and CD31, excluding contamination with leukocytes and epithelial population, as we observed. Moreover, MSC must differentiate from other cell line, indicating the most important MSC property that is the ability to generate other kind of cell. Pictures showed here prove that the cells used in the therapy were MSC.

The MSC administration in ischemic animals reduced the renal function impairment. These data were in agreement with what it was described in the literature. ${ }^{16-19}$ Nevertheless, the mechanism involved in such protection is still uncertain. In our study, we exploited the immunomodulatory capacity of MSC in reversing the immune response triggered by IRI. Our initial results showed that MSC induced a higher anti-inflammatory cytokines expression (IL-4 and IL-10) after acute and down-regulation of pro-inflammatory cytokines expression such as IL- $1 \beta$ and TNF- $\alpha$.

Interleukin 6 (IL-6) is a pleiotropic cytokine released after an organ injury. Moreover, increased expression of IL- 6 was also observed in the kidney following whole body IRI. ${ }^{33}$ IL-6 stimulates the tubular regeneration after glycerol-induced ARF and increases the expression of c-met in the renal cortex. MSC seems to produce IL-6 themselves (data not show). So the increased IL-6 expression should be due to the MSC presence, together with the expression induced by the injury. At early points, such expression does not seem to be deleterious, but IL- 6 can counteract a possible anti-fibrotic effect of the MSC.

IL-1 receptor-null mice, although equally susceptible to IRI, exhibited a fast return of renal function following ischemia. These results suggest that IL-1 plays a negative role in repairing the renal function. ${ }^{34}$ By down regulating the IL1 $\beta$, the MSC treatment should act to accelerate the after injury regeneration phase. This is corroborated by the higher expression of PCNA, analyzed by immunohistochemistry, and the higher ratio of $\mathrm{BCl} 2 / \mathrm{Bad}$ at $\mathrm{MSC}$ treated animals.

In the remnant model, IL-1 $\beta$ RNAm expression was reduced in the MSC-treated animals after 12 weeks in only one MSC shot, while IL-4 was increased. This modulator cytokines expression in a renal model of glomerulosclerosis and tubule-interstitial the remnant model - may have two sides: it should modulate the inflammation, leading to an anti-inflammatory picture; also, the TH1/TH2 balance can be related to the matrix remodeling. So, the TH2 (IL-4) responses could activate collagen deposition, and TH1 (IL-1) could inhibits this process. ${ }^{34,35}$ In our data, we showed an augmentation of the Th2 cytokines and a decrease in the Th1related one. When putting all results together, these effects did not lead to an amelioration of the renal function parameters. Despite the MSC administration, fibrosis was not reduced. We assume that although beneficial at early stages of acute injury, the persistence of higher levels of Th2 cytokines might promote fibrosis in a microenvironment prone to it.

So, we analyze some molecules present at fibrosis cascade. It seems that MSC in this model do not interfere in the fibrosis cascade (Figure 7B and C), although there was a trend to decrease with no statistical significance. We analyzed the MCP-1, Smad7, TGF- $\beta$ and PAI-1, which corresponded to a broad range of molecules involved in fibrogenesis. Monocyte chemoattractant protein-1 (MCP-1) is a potent macrophage recruitment stimulator. ${ }^{36} \mathrm{MCP}-1$ is present 
during the crescent formation and development of interstitial fibrosis, indicating that added to the recruiting inflammatory cells, this chemokine is critically involved in irreversible tissue damages. Transforming growth factor-beta (TGF- $\beta$ ), a prototype of multifunctional cytokine, is a key-regulator of the extracellular matrix (ECM) assembly and remodeling. Smad7 has been identified as a negative regulator of TGF- $\beta / \mathrm{Smad}$ signaling that is responsive to TGF- $\beta$ itself, presumably as part of a self-inhibitory feedback loop, and to factors known to antagonize TGF- $\beta$ 's activities including TNF- $\alpha$ and IFN- $\gamma$. Our results demonstrated that TGF- $\beta$ was only marginally reduced with no modification of the Smad-7 levels.

The MSC treatment in the remnant model did not halt or reverse the fibrosis. Only the PAI-1 RNAm expression was significantly reduced. PAI-1 modulates scarring in a complex manner, including effects on cell migration, matrix turnover, and macrophage infiltration. ${ }^{37}$ It appears that the PAI-1 expression may be induced at several steps along this pathway by the renin, angiotensin II, angiotensin IV, and aldosterone. Since the remnant model leads to an increase in the blood pressure, PAI-1 is expressed in nontreated kidney animals as well. The MSC administration leads to a decreased expression in the PAI-1, despite there were no differences in the blood pressure of these animals (data not shown). Somehow, MSC should modulate PAI-1 RNAm expression.
The T helper $1\left(\mathrm{~T}_{\mathrm{H}} 1\right)$-cell cytokine interferon- $\gamma(\mathrm{IFN}-\gamma)$ directly suppresses the collagen synthesis by fibroblasts. This is accomplished by regulating the balance of the matrix metalloproteinase (MMP) and the tissue inhibitor of the matrix metalloproteinase (TIMP) expression, thereby controlling the collagen degradation and synthesis rates, respectively. ${ }^{35}$ Our results showed an increased TIMP-1 RNAm expression in non-treated and MSC-treated animal's expression compared to saline-treated animals. An unbalanced picture was formed: more inhibitor TIMP-1 RNAm was expressed than MMP-9.

MSC has a great potential in several experimental disease models, although the mechanism of action is still being discussed. Our data support a paracrine effect where the immunomodulatory ability of MSC favored a Th2 immune response. This is important, since the early inflammation is important to the tissue fibrosis development. It is worth to mention that MSC are cells prone to differentiate in mesenchymal tissue, namely, fibroblasts, for instance. If the inflammation persists, it can be expected an increase in fibrosis if the MSC are influenced by the microenvironment. Although the overall level of some pro-inflammatory cytokines decreased, the functional parameters and gene transcripts do not demonstrate a benefit of this treatment in chronic related models.

\section{RESUMO}

A utilização das células-tronco surge como uma nova terapia para doenças renais. Em modelos animais agudos, o tratamento com célulastronco melhora a função renal. Porém, o mecanismo envolvido nesse processo ainda é desconhecido. Objetivo: Avaliar se a proteção renal após a administração de células-tronco decorre da modulação de padrões inflamatórios. Métodos: Células-tronco mesenquimais foram isoladas das medula ósseas de ratos Wistar-EPM. O modelo de isquemia e reperfusão foi realizado através do clampeamento bilateral dos pedículos renais por $1 \mathrm{~h}$. Após $6 \mathrm{~h}$ de reperfusão, foram administradas aos animais $2.10^{5}$ de células-tronco endovenosamente. Nos modelos de nefrectomia 5/6, os animais foram tratados após 2 semanas com $1.10^{6}$ de células-tronco iv. Resultados: Após 24 e $48 \mathrm{~h}$ de reperfusão, os animais tratados apresentaram melhora na função renal no modelo agudo, que se associou a uma redução na expressão do RNAm de IL1 $\beta$, IL-6 e TNF no tecido renal e aumento dos níveis de IL-4. A expressão de PCNA e a relação BCl2/Bad estavam maiores nos animais tratados. No modelo crônico, a modulação das citocinas IL1 $\beta$ e IL4 se mantiveram, apesar de não haver melhora funcional. A expressão de RNAm de TGF $\beta$ e Smad7, assim como de MMP-9 e TIMP-1 não se mostraram diferentes dos animais tratados, entretanto PAI-1 mostrou-se significante reduzido. Conclusão: A terapia com Células-tronco mesenquimais realmente modula a resposta inflamatória tanto em modelos renais agudos como em crônicos, possivelmente acelerando o reparo tubular. Porém, a longo prazo, outros parâmetros como fibrose, não se mostram alterados pela terapia.

Palavras-Chave: Transplante de Células-Tronco Mesenquimais; Insuficiência Renal Crônica.

\section{REFERENCES}

1. Ikeda M, Prachasilchai W, Burne-Taney MJ, Rabb H, Yokota-Ikeda N. Ischemic acute tubular necrosis models and drug discovery: a focus on cellular inflammation. Drug Discov Today. 2006:11(7-8);364-70.

2. Friedewald JJ, Rabb H. Inflammatory cells in ischemic acute renal failure. Kidney Int. 2004:66(2);486-91.

3. Pinheiro HS, Camara NO, Noronha IL, Maugeri IL, Franco MF, et al. Contribution of CD4+ $\mathrm{T}$ cells to the early mechanisms of ischemia- reperfusion injury in a mouse model of acute renal failure. Braz J Med Biol Res. 2007:40(4);557-68.

4. Kher A, Meldrum KK, Wang M, Tsai BM, Pitcher JM, Meldrum DR. Cellular and molecular mechanisms of sex differences in renal ischemia-reperfusion injury. Cardiovasc Res. 2005:67(4);594-603.
5. Devarajan P. Update on mechanisms of ischemic acute kidney injury. J Am Soc Nephrol. 2006:17(6);1503-20.

6. Rabb H, O'Meara YM, Maderna P, Coleman P, Brady HR. Leukocytes, cell adhesion molecules and ischemic acute renal failure. Kidney Int. 1997:51(5);1463-8

7. Mene P, Polci R, Festuccia F. Mechanisms of repair after kidney injury. J Nephrol. 2003:16(2);186-95.

8. Nony PA, Schnellmann RG. Mechanisms of renal cell repair and regeneration after acute renal failure. J Pharmacol Exp Ther. 2003:304(3);905-12.

9. Nigam S, Lieberthal W. Acute renal failure. III. The role of growth factors in the process of renal regeneration and repair. Am J Physiol Renal Physiol. 2000:279(1);F3-F11.

10. Harris RC. Growth factors and cytokines in acute renal failure. Adv Ren Replace Ther. 1997:4(2 Suppl 1);43-53. 
716 Patricia Semedol, Carolina Gardini Palasio ${ }^{l}$, Cassiano Donizetti Oliveiral, Carla Quarim Feitozal', Giselle Martins Gonçalves ${ }^{l}$, Pamella Mei Wang ${ }^{l}$, Marcos Antonio Cenedeze ${ }^{l}$, Vicente de Paula Teixeira'; ${ }^{2}$ Marlene Antônia dos Reis ${ }^{2}$, Alvaro Pacheco-Silva', Niels Olsen Saraiva Câmara ${ }^{1,3}$.

11. Wynn TA. Common and unique mechanisms regulate fibrosis in various fibroproliferative diseases. J Clin Invest. 2007:117(3);524-9.

12. Friedenstein AJ, Chailakhjan RK, Lalykina KS. The development of fibroblast colonies in monolayer cultures of guinea-pig bone marrow and spleen cells. Cell Tissue Kinet. 1970;3(4):393-403.

13. Dominici M, Le Blanc K, Mueller I, Slaper-Cortenbach I, Marini F, Krause D, Deans R, Keating A, Prockop Dj, Horwitz E. Minimal criteria for defining multipotent mesenchymal stromal cells. The International Society for Cellular Therapy position statement. Cytotherapy. 2006;8(4):315-7.

14. Herrera MB, Bussolati B, Bruno S, Fonsato V, Romanazzi GM, Camussi G. Mesenchymal stem cells contribute to the renal repair of acute tubular epithelial injury. Int J Mol Med. 2004:14(6);1035-41.

15. Duffield JS, Park KM, Hsiao LL, Kelley VR, Scadden DT, Ichimura T, et al. Restoration of tubular epithelial cells during repair of the postischemic kidney occurs independently of bone marrow-derived stem cells. J Clin Invest. 2005:115(7);1743-55.

16. Lin F, Moran A, Igarashi P. Intrarenal cells, not bone marrow-derived cells, are the major source for regeneration in postischemic kidney. J Clin Invest. 2005:115(7);1756-64.

17. Morigi M, Imberti B, Zoja C, Corna D, Tomasoni S, Abbate M, et al. Mesenchymal stem cells are renotropic, helping to repair the kidney and improve function in acute renal failure. J Am Soc Nephrol. 2004:15(7);1794-804.

18. Lange C, Togel F, Ittrich H, Clayton F, Nolte-Ernsting C, Zander AR, et al. Administered mesenchymal stem cells enhance recovery from ischemia/reperfusioninduced acute renal failure in rats. Kidney Int. 2005:68(4);1613-7.

19. Togel F, Hu Z, Weiss K, Isaac J, Lange C, Westenfelder C. Administered mesenchymal stem cells protect against ischemic acute renal failure through differentiationindependent mechanisms. Am J Physiol Renal Physiol. 2005:289(1);F31-42.

20. Semedo P, Wang PM, Andreucci TH, Cenedeze MA, Teixeira VP, Reis MA, et al. Mesenchymal stem cells ameliorate tissue damages triggered by renal ischemia and reperfusion injury. Transplant Proc. 2007:39(2);421-3.

21. Kale S, Karihaloo A, Clark PR, Kashgarian M, Krause DS, Cantley LG. Bone marrow stem cells contribute to repair of the ischemically injured renal tubule. J Clin Invest. 2003:112(1);42-9.

22. Poulsom R, Forbes SJ, Hodivala-Dilke K, Ryan E, Wyles S, Navaratnarasah S, et al. Bone marrow contributes to renal parenchymal turnover and regeneration. J Pathol.2001:195(2); 229-35.
23. Duffield JS, Bonventre JV. Kidney tubular epithelium is restored without replacement with bone marrow-derived cells during repair after ischemic injury. Kidney Int. 2005:68(5);1956-61.

24. Stagg J. Immune regulation by mesenchymal stem cells: two sides to the coin. Tissue Antigens. 2007:69(1);1-9

25. Le Blanc K, Ringden O. Immunobiology of human mesenchymal stem cells and future use in hematopoietic stem cell transplantation.

Biol Blood Marrow Transplant. 2005:11(5);321-34.

26. Aggarwal S, Pittenger MF. Human mesenchymal stem cells modulate allogeneic immune cell responses. Blood. 2005:105(4);1815-22.

27. Rasmusson I. Immune modulation by mesenchymal stem cells

Exp Cell Res. 2006:312(12);2169-79.

28. Le Blanc K. Mesenchymal stromal cells: Tissue repair and immune modulation. Cytotherapy. 2006:8(6);559-61

29. Bonventre JV. Dedifferentiation and proliferation of surviving epithelial cells in acute renal failure. J Am Soc Nephrol. 2003:14 Suppl 1;S55-61.

30. Burne-Taney MJ, Yokota N, Rabb H. Persistent renal and extrarenal immune changes after severe ischemic injury. Kidney Int. 2005:67(3);1002-9

31. Pittenger MF, Mackay AM, Beck SC, Jaiswal RK, Douglas R, Mosca JD, et al. Multilineage potential of adult human mesenchymal stem cells. Science. 1999:284(5411);143-7

32. Burne-Taney MJ, Kofler J, Yokota N, Weisfeldt M, Traystman RJ, Rabb H. Acute renal failure after whole body ischemia is characterized by inflammation and $\mathrm{T}$ cell-mediated injury. Am J Physiol Renal Physiol. 2003:285(1);F87-94.

33. Homsi E, Ribeiro-Alves MA, Lopes de Faria JB, Dias EP. Interleukin-6 stimulates tubular regeneration in rats with glycerol-induced acute renal failure. Nephron. 2002:92(1);192-9.

34. Haq M, Norman J, Saba SR, Ramirez G, Rabb H. Role of IL-1 in renal ischemic reperfusion injury. J Am Soc Nephrol. 1998: 9(4); 614-9

35. Wynn TA. Fibrotic disease and the $\mathrm{T}(\mathrm{H}) 1 / \mathrm{T}(\mathrm{H}) 2$ paradigm. Nat Rev Immunol. 2004:4(8);583-94.

36. Lloyd CM, Dorf ME, Proudfoot A, Salant DJ, Gutierrez-Ramos JC. Role of MCP-1 and RANTES in inflammation and progression to fibrosis during murine crescentic nephritis. J Leukoc Biol. 1997:62(5);676-80.

37. Fogo A. Renal fibrosis: not just PAI-1 in the sky J. Clin. Invest 2003:112;326-328

JBT J Bras Transpl. 2007; 10:709-716 